JURNAL PENDIDIKAN USIA DINI

DOI: https://doi.org/10.21009/JPUD.112

DOI:https://doi.org/10.21009/JPUD.112.03

\title{
PENINGKATAN KEMAMPUAN MUSIKALITAS MELALUI BERMAIN ALAT MUSIK DOL
}

\author{
ELINDRA YETTI ${ }^{1}{ }^{-}$ICHA KHAIRIAH ${ }^{2}$ \\ Universitas Negeri Jakarta \\ Jl. Rawamangun Muka, Jakarta Timur. \\ E-mail: elindrayetti@unj.ac.id
}

\begin{abstract}
This study aims to know whether the use instrument dol can the ability of children in early childhood musical Paud Al-khair Air Napal Sub District, Bengkulu Utara Regency, Bengkulu Province, 2016. The method used is action research model Kemmis \& Mc Taggart. The subjects of this research were 17 children of group B in Paud Al-khair. The study was conducted in two cycles consisting of nine meetings in each the cycle. Techniques of data collection was done through observation, interviews and document study. Techniques of data analysis in this research is the analysis of qualitative data and quantitative data analysis. The results showed that the musical abilities of children in group B in PAUD Al-khair increased after they performed activities play a musical instrument dol. Scores of children's musical ability was recorded at 36.5 at the pre-cycle. Musical ability scores increased to 52.4 at the end of the first cycle, and continuously increased to 59.2 at the end of the second cycle. The results of this study implies that playing a musical instrument dol can be used as one way to improve musical ability in children early age.
\end{abstract}

Keywords: Ability Music, Playing musical instruments Dol

\begin{abstract}
Abstrak:Penelitian ini bertujuan untuk mengetahui proses dan hasil bermain alat musik dol untuk meningkatkan kemampuan musikal anak di PAUD Al-khair Kecamatan Air Napal Kabupaten Bengkulu Utara-Bengkulu, Tahun 2016. Metode penelitian yang digunakan adalah penelitian tindakan dengan model Kemmis \& Mc Taggart. Subjek penelitian adalah anak kelompok B sebanyak 17 orang. Penelitian dilakukan dalam dua siklus yang terdiri dari sembilan kali pertemuan pada setiap siklus. Tekhnik pengumpulan data dilakukan melalui observasi, wawancara dan studi dokumen. Tekhnik analisis data dalam penelitian ini adalah analisis data kualitatif dan analisis data kuantitatif. Hasil penelitian menunjukkan bahwa kemampuan musikal anak kelompok B di PAUD Al-khair mengalami peningkatan setelah mereka melakukan kegiatan bermain alat musik dol. Skor kemampuan musikal anak tercatat sebesar 36,5 pada tahap pra-siklus. Skor kemampuan musikal meningkat menjadi 52,4 pada akhir siklus I, dan terus mengalami peningkatan menjadi 59,2 pada akhir siklus II. Hasil penelitian ini memberi implikasi bahwa bermain alat musik dol dapat dijadikan sebagai salah satu cara untuk meningkatkan kemampuan musikalitas pada anak-anak usia diri.
\end{abstract}

Kata Kunci: Kemampuan Musik, Bermain alat musik Dol. 
Peningkatan Kemampuan Musikalitas.... Elindra \& Icha

\section{PENDAHULUAN}

Usia dini merupakan masa dimana pertumbuhan dan perkembangan anak melejit dengan cepat. Menurut Nasional Association In Education for Young Children (NAEYC) bahwa anak usia dini berada pada rentang 0-8 tahun. Pada usia ini anak mulai sensitif untuk menerima berbagai upaya perkembangan seluruh potensi anak. Terlebih lagi dengan kemampuan musikal sangat penting bagi perkembangan anak.

Musik banyak berkontribusi dalam perkembangan emosional, sosial, fisik, bahasa, terutama pada kognitif anak. Karena dengan musik, belahan otak kanan anak bekerja dengan baik melalui suara, nada, irama dan melodi yang didengar. Penelitian terbaru juga mengatakan bahwa dengan musik tidak hanya membantu kerja otak belahan kanan semata, melainkan belahan otak kiri bekerja dengan baik melalui lirik-lirik yang ada pada sebuah lagu dan nyanyian pada musik. Oleh sebab itu, dengan musik dapat menyeimbangkan belahan otak kanan dan belahan otak kiri manusia.

Tetapi seringkali orangtua menganggap kemampuan musikal yang dimiliki anak hanya sebagai suatu kesenangan dan hiburan semata. Anggapan seperti ini pula yang membuat guru kurang tertarik dan kurang memperhatikan kemampuan musikal yang dimiliki anak sehingga kurang tertarik untuk menstimulasi kemampuan musikal anak. Padahal jika kemampuan musikal berkembang dengan optimal maka dapat mengembangkan semua kecerdasan pada anak.

Singkatnya, perlu adanya perhatian khusus dalam menstimulasi perkembangan musik anak, karena musik sangat penting bagi kehidupan seseorang manusia, terutama untuk anak usia dini guna menstimulasi perkembangan dan kecerdasan anak. Anggapan kemampuan musikal hanya untuk orang yang berbakat harus dihapuskan karena kemampuan musikal bisa dikembangkan dengan distimulasi tentunya dengan cara yang tepat dan berulang. 
Berdasarkan hasil observasi yang dilakukan pada Kelompok B PAUD Pasar Tebat Kecamatan Air Napal Kabupaten Bengkulu Utara. Dari 17 anak dengan rincian 10 anak laki-laki dan 7 anak perempuan hanya ada 4 anak yang memiliki kemampuan musikal sesuai harapan. Dari observasi tersebut dapat terlihat bahwa kemampuan (1) meniru pulsa irama dengan konsisten; (2) merespon irama dengan ketukan dan gerakan; (3) membedakan ketukan dengan tempo cepat-lambat dan ketukan dengan dinamik lembut-keras; masih sangat rendah.

Hal-hal tersebut sangat memprihatinkan karena irama atau penanaman rasa irama adalah unsur utama dalam bermusik. Karena kemampuan musikal bukan hanya bernyanyi dan bermain alat musik saja melainkan juga mengenal unsur-unsur dalam musik. Maka peneliti akan melakukan tindakan dengan bermain alat musik dol untuk meningkatkan kemampuan musikal. Sebab, dol merupakan salah satu alat musik tradisional Bengkulu dimana PAUD 228
Al-Khair berada yaitu di Provinsi Bengkulu.

Berdasarkan latar belakang tersebut peneliti mengangkat judul penelitian "Peningkatan Kemampuan musikal Melalui Bermain Alat Musik Dol (Penelitian Tindakan di kelompok B PAUD Al-Khair Desa Pasar Tebat, Kecamatan Air Napal kabupaten Bengkulu Utara Provinsi Bengkulu, tahun 2016)"

\section{KAJIAN TEORITIK}

\section{Kemampuan Musikal}

Kemampuan musikal tidak ataupun bermain alat musik semata, tetapi ditekankan pada kepekaan terhadap bunyi musik, baik itu tinggi rendah nada, ritme, maupun melodi. Seperti yang dijelaskan oleh Driver (Pica, 2013: 26) bahwa "Unfortunately, a child's musical ability is too often judged by an ability to sing or play instrument".

Beberapa studi yang telah dilakukan oleh peneliti dibidang kemampuan musikal dapat memberikan landasan tentang cakupan kemampuan musikal, diantaranya dari 
Peningkatan Kemampuan Musikalitas.... Elindra \& Icha

penelitian sumaryanto (2014: 4)

menyimpulkan bahwa kemampuan musikal menunjuk pada kemampuan bawaan yang melekat pada individu dalam memberikan respon terhadap unsur-unsur musikal yaitu, irama, melodi dan harmoni. Ternyata kemampuan musikal merupakan bawaan dari gen individunya.

"Perceptual musical abilities are acquired in the area of sound phenomena,in which learning is related to the formation of concepts based on perceptual experience and thinking in terms of sounds and meanings contained within the structure of music”. (Bonn, 2013: 30)

Kemampuan persepsi musik diperoleh di daerah fenomena suara, di mana belajar adalah terkait dengan pembentukan konsep berdasarkan persepsi pengalaman dan pemikiran dalam hal suara dan makna yang terkandung dalam struktur musik.

"Musical ability as a term is used to describe the sensitivity for music, the ability to understand music, and/or the ability to produce music. There is no standard definition, and it is hard to measure musical ability. One can only measure how well a person can perceive musical stimuli such as small changes in pitch, loudness, rhythm, and other sub-domains of music processing." (caroline: 2015: 1)

Mudjilah (2011: 3) mengungkapkan dalam penelitiannya tentang pengembangan tes kemampuan musikal anak ialah:

Berdasarkan pendapat para tokoh diatas, maka dapat disimpulkan bahwa kemampuan musikal adalah kesanggupan dalam memahami konsep musikal yang meliputi kemampuan (1) membedakan, (2) menirukan, (3) merespon yang berhubungan dengan unsur-unsur musik yang meliputi suara, irama dan melodi.

\section{Bermain Alat Musik Dol}

Memainkan alat musik adalah salah satu sarana utama dalam pembuatan musik dan dinikmati oleh anak-anak pada semua usia. Instrumen yang menyenangkan dalam bermain adalah cara mudah untuk membuat musik. Sebagaimana telah diungkapkan Greenberg bahwa: 
"Playing instrument is one of the principal means of music making and is enjoyed by children af all age. Instruments are fun to handle and play and are an easy way to make musik." (Grenberg, 1979: 201).

Menurut Pica (2013: 198) bahwa:

"Playing instruments and exploring environmental sound should accur early and often in a child's life. Both contribute to the child's overal music education and provide an awareness of sound that can enrich daily living".

Memainkan alat musik dan mengeksplor suara harus tepat dan sering dalam kehidupan seorang anak. Keduanya berkontribusi dalam pendidikan musik anak dan memberikan kesadaran dari suara yang dapat memperkaya kehidupan seharihari.

Menurut Jamalus (1988: 66) bahwa bermain musik dengan menggunakan alat-alat musik kelas, memberikan pengalaman yang dapat meningkatkan minat anak-anak dalam belajar musik. Pada umumnya anak- anak ingin memegang alat musik itu, dan ingin mencoba memainkannya.

Dol adalah salah satu alat musik tradisional dari provinsi Bengkulu yang dimainkan dengan cara dipukul. Dol merupakan salah satu jenis alat musik perkusi yang berupa gendang, dengan menggunakan dua stik sebagai alat pemukulnya.

Berdasarkan pemaparan diatas maka dapat ditarik kesimpulan bahwa bermain alat musik dol adalah kegiatan dengan menggunakan salah satu alat musik tradisional Bengkulu berjenis gendang yang memberikan pengalaman dalam menghasilkan musik sehingga dapat dilakukan dan dinikmati oleh anak dari semua usia dengan cara memukul permukaannya menggunakan stik.

\section{METODE PENELITIAN}

Metode penelitian yang digunakan adalah penelitian tindakan (Action Research) yang bersifat partisipatif dan kolaboratif. Penelitian tindakan memiliki 2 (dua) aktivitas yang dilakukan secara simultan, yaitu aktivitas tindakan (action) dan 
Peningkatan Kemampuan Musikalitas.... Elindra \& Icha

aktivitas penelitian (research). Desain penelitian tindakan yang digunakan dalam penelitian ini adalah adalah model Kemmis dan Taggart yang menggunakan 4 (empat) komponen penelitian tindakan, yaitu: 1) perencanaan; 2) tindakan; 3) observasi; dan 4) refleksi. Model penelitian ini bertujuan untuk memperbaiki praktek pembelajaran dan meningkatkan mutu proses pembelajaran.

Instrumen pengumpulan data yang digunakan dalam penelitian ini adalah non tes, yaitu: 1) lembar observasi; 2) catatan wawancara; 3) catatan lapangan; dan 4) dokumentasi; dengan menggunakan teknik pengumpulan data berupa observasi dan wawancara.

Teknik analisis data yang dilakukan dalam penelitian ini yaitu teknik analisis data kualitatif dan analisis data kuantitatif.Analisis data kualitatif mengunakan teknik menurut Milles dan Huberman yang terdiri dari: data collection, data reduction, data display dandata conclusing drawing/verification.

Analisis data kuantitatif menggunakan deskriptif statistik dengan menggunakan tabel dan grafik. Adapun skor tertinggi yaitu tiap butir observasi adalah 4, sedangkan jumlah butir observasi adalah 18, maka skor tertinggi adalah 72 .

\section{HASIL DAN PEMBAHASAN \\ Pra-siklus}

Sebelum pemberian tindakan, dilakukan penilaian pra-siklus untuk mengetahui sejauh mana keterampilan awal kemampuan musikal anakakan di paparkan dalam grafik berikut ini:
Gambar grafik di atas menunjukkan bahwa TCPtertinggi

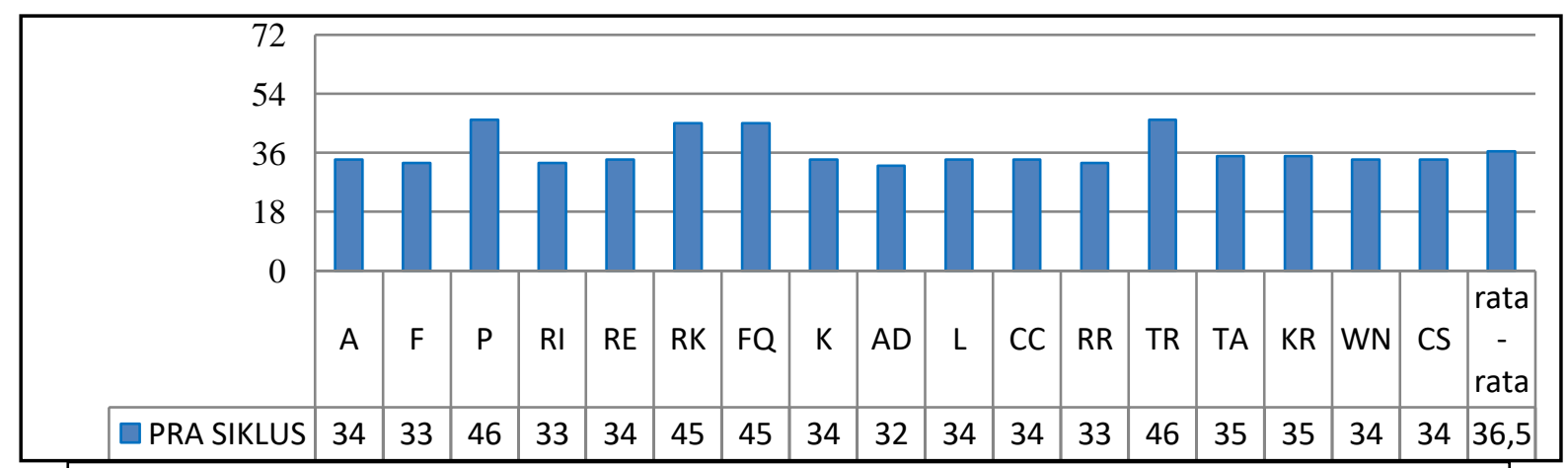


diperoleh ananda $\mathrm{P}$ dengan $\mathrm{TCP}_{\min } 46$; TR dengan $\mathrm{TCP}_{\min }$ 46; RK dengan $\mathrm{TCP}_{\min }$ 45; dan FQ dengan $\mathrm{TCP}_{\text {min }} 45$ yang masuk dalam kategori mulai berkembang (MB). TCP terendah diperoleh $\mathrm{AD}$ dengan $\mathrm{TCP}_{\min } 32$ yang masuk dalam kategori belum berkembang(BB). Berdasarkan gambar grafik tersebut diatas, dapat juga dilihat bagaimana perbedaan tinggi danrendah skala penilaian yang telah diperoleh setiap anak

\section{Siklus I}

Skor penilaian TCP rata-rata kelas pada kegiatan pra-siklus 37 dan meningkat menjadi 52,41 pada kegiatan siklus I. yang telah berada pada kategori berkembang sangat baik (BSB), 12 orang anak yang berada pada kategori berkembang sesuai harapan (BSH) dan 3 orang anak berada pada kategori mulai berkembang (MB). Berikut grafik yang menggambarkan peningkatan skor penilaian kemampuan musikalanak

Pada siklus I ini, keseluruhan anak sudah mengalami peningkatan setelah diberikan tindakan/intervensi, akan tetapi hanya 4 orang yang memenuhi skor penilaian $\mathrm{TCP}_{\text {min }}$ sebesar 54.

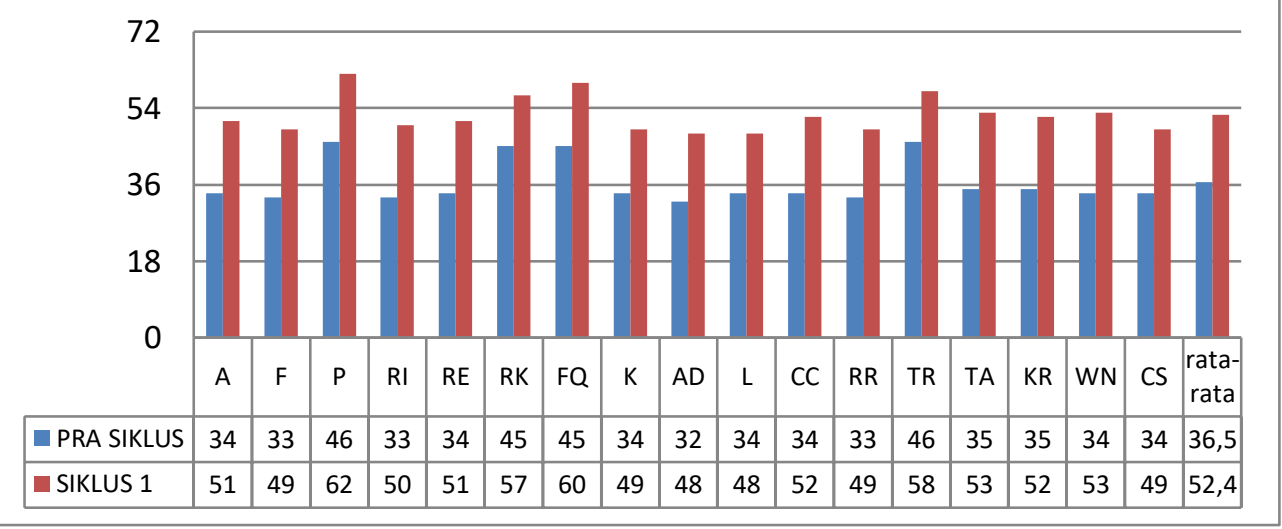

Grafik 2. Kemampuan Musikal Pada Siklus I Di Kelompok B PAUD Al-Khair Bengkulu Tahun 2016

Terlihat pada data hasil penilaian kegiatan siklus I, terdapat 2 orang anak
Oleh karena itu penelitian ini akandilanjutkan pada siklus II karena 
Peningkatan Kemampuan Musikalitas.... Elindra \& Icha

belum mencapai kriteria keberhasilan yaitu $71 \%$ dari jumlah anak yaitu 13 orang anak dari 17 orang anak pada kelompok B PAUD Al-khair, Bengkulu.

\section{Siklus II}

Skor penilaian TCP rata-rata kelas pada kegiatan pra-siklus 37, meningkat menjadi 52,4 pada kegiatan siklus I dan meningkat kembali menjadi 59,4 pada kegiatan siklus II. Terlihat pada hasil penilaian kegiatan siklus II (lihat grafik 3) terdapat 9 orang anak yang berada pada kategori berkembang sangat baik (BSB) dan 8 orang anak telah berada pada kategori berkembang sesuai harapan (BSH). tertinggi diperoleh $\mathrm{P}$ dengan skor penilaian $\mathrm{TCP}_{\min }$ sebesar 70 yang masuk dalam kategori berkembang sangat baik (BSB), sedangkan TCP terendah diperoleh $\mathrm{AD}$ dan $\mathrm{CS}$ dengan skor penilaian $\mathrm{TCP}_{\min }$ sebesar 53 yang masuk pada kategori berkembang sesuai harapan (BSH).

Kriteria keberhasilan menurut Mills, yakni $71 \%$ akan terpenuhi apabila 13 dari 17 orang anak yang sudah berhasil mencapai $\mathrm{TCP}_{\min } 54$ dan $\mathrm{TCP}_{\max }$ sebesar 72 yang telah disepakati oleh peneliti dan kolaborator. Berdasarkan data yang diperoleh pada kegiatan siklus II,

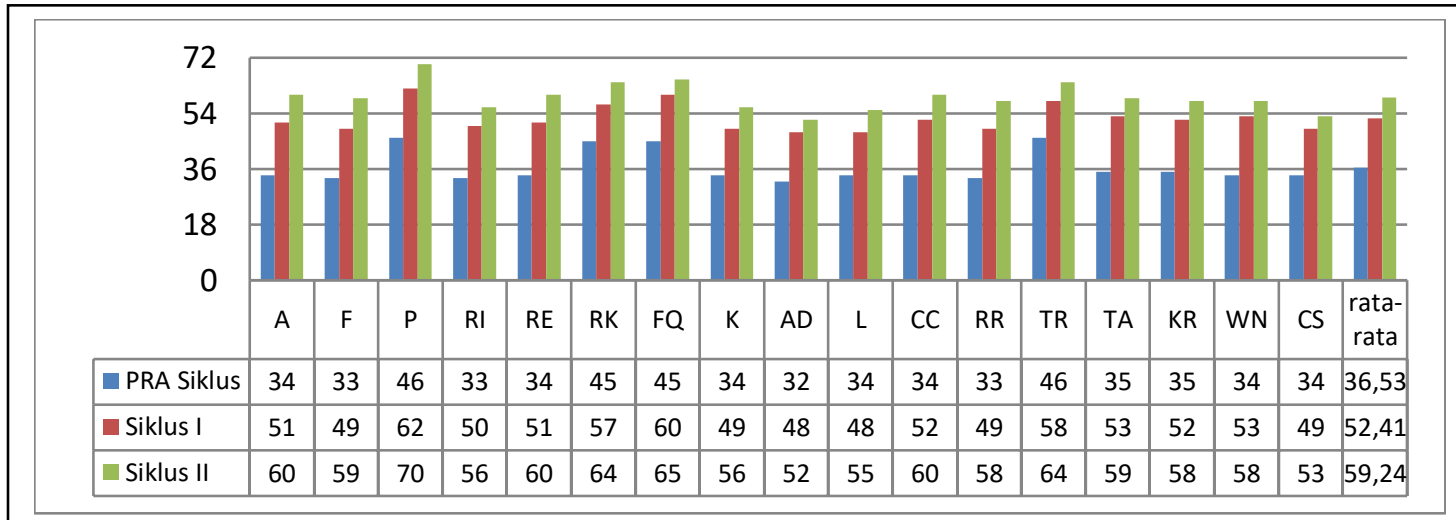

Grafik 3. Kemampuan Musikal Pada Siklus II di Kelompok B PAUD Al-Khair Bengkulu Tahun 2016

Grafik berikut menunjukkan skor hasil penilaian TCP kegiatan siklus II
15 dari 17 orang anak telah berhasil mecapai skor penilaian $\mathrm{TCP}_{\min } 54$. 
Oleh karena itu, pemberian tindakan/intervensi pada siklus II ini sudah mencapai keberhasilan minimal $71 \%$, maka rata-rata kelas anak sudah berada dalam kategori berkembang sangat baik (BSB). Berdasarkan hasil pengamatan dari kegiatan pra-siklus, siklus I dan siklus II, maka pemberian intervensi/tindakan dengan bermain alat musik dol dapat meningkatkan kemampuan musikal anak pada kelompok BPAUD Al-khair, Bengkulu tahun 2016.

Setelah melakukan kegiatan prapenelitian sampai pada diberikan tindakan dalam kegiatan siklus I dan siklus II, maka hasil pengamatan peneliti dan kolaborator menunjukkan bahwa pelaksanaan tindakan yang dilakukan sudah berjalan sesuai dengan rencana. Pada kegiatan siklus I, pemberian intervensi/tindakan kepada anak melalui bermain alat musik dol sudah memberikan efektivitas yang baik untuk mencapai kriteria yang diinginkan dalam upaya meningkatkan kemampauan musikal.

Pada kegiatan siklus I, perkembangan kemampuan musikal 234 yang menfokuskan pada unsur irama setiap anak telah mengalami peningkatan, baik dari aspek 1) meniru irama; 2) merespon irama; dan 3) membedakan irama. Pada aspek meniru irama indikator meniru pulsa irama sesuai detakan jarum jam masih sangat membutuhkan stimulasi dan latihan serta kesabaran ketika anak melakukan kegiatan bermain alat musik dol sehingga perlu ditingkatkan kembali pada siklus II. Pada aspek merespon irama dengan ketukan juga masih sangat membutuhkan stimulasi, terutama dalam merespon irama dengan bebas serta merespon irama dengan gerakan. Anak-anak masih merespon dengan lambat dan merespon gerakan denga ragu-ragu dan tidak percaya diri.

Untuk aspek membedakan irama indikator membedakan irama tempo cepat-lambat dan meniru dinamik keras-lembut juga masih sangat membutuhkan stimulasi karena anak masih ragu dan lamban dalam membedakan tempo dan dinamik.

Selain itu, alokasi waktu pada kegiatan pembelajaran yang masih 
Peningkatan Kemampuan Musikalitas.... Elindra \& Icha

terbatas juga merupakan salah satu bahan evaluasi dan refleksi pada kegiatan siklus I ini. Hal tersebut membawa dampak pada pelaksanaan atau pemberian tindakan serta berpengaruh pada hasil pengamatan dan penilaian dalam meningkatkan kemampuan musikal sehingga diperlukan perbaikan dalam pemberian tindakan/intervensi. Perbaikan dan peningkatan kemampuan musikal pada kegiatan siklus II akan dilakukan untuk seluruh aspek, indikator dan butir guna mendapatkan hasil yang lebih maksimal lagi. Selain mendapatkan hasil evaluasi dari refleksi terhadap pelaksanaan tindakan pada kegiatan siklus I, peneliti dan kolaborator menyimpulkan bahwa kemampuan musikal anak akan meningkat apabila terus diberikan stimulasi-stimulasi yang sesuai dengan tahapan perkembangan anak dan diberlakukannya suatu pembiasaan dan terus menerus.

Indikator yang menjadi bahan pertimbangan/evaluasi dan refleksi pada pemberian tindakan di siklus I yang perlu ditingkatkan pada siklus II adalah: 1) meniru pulsa irama; 2) merespon irama; dan 3) membedakan irama dari ketukan.

Peneliti dan kolaborator mengevaluasi kekurangan yang ditemukan, yaitu pada kegiatan meniru pulsa irama. Anak-anak sudah dapat meniru pulsa irama sesuai detakan jam namun belum konsisten sampai 1 menit dan meniru irama dengan mengiri lagu juga belum konsisten sampai lagu berakhir. Bermain alat musik dol ini memberikan pengalaman yang baru bagi anak-anak karena dalam kegiatan ini mereka telah mengeksplor kemampuan musikal nya terutama dalam unsur irama.

Pada indikator merespon irama untuk butir merespon irama dengan bebas masih membutuhkan stimulasi dan arahan. Karena anak masih ragi dan lamban dalam memberikan respon dari ketukan awal yang guru berikan, tetapi pada kegiatan siklus II ini anakanak sudah dapat merespon ketukan awal yang diberikan guru dengan bebas dan cepat tanggap. Pada indikator membedakan irama awalnya anak masih ragu dalam membedakan 
tempo cepat-lambat dan dinamik keras-lembut, namun setelah diberikan tindakan pada siklus II, anak terlihat lebih cepat membedakannya dengan benar.

Bermain alat musik dol yang telah dilakukan memberikan pengalaman dan pembiasaandalam beberapa pertemuan, sehingga mampu meningkatkan kemampuan musikal pada kelompok B PAUD Al-khair, Bengkulu.

Kemampuan musikal anak mengalami peningkatan yang lebih baik dibandingkan pada awal kegiatan dilakukan walaupun peningkatan tersebut mungkin belum sepenuhnya maksimal karena keterbatasan peneliti dalam melakukan kegiatan penelitian. Peningkatan setiap anak dapat dilihat dari hasil observasi atau instrumen penelitian yang dilampirkan pada akhir kegiatan siklus I dan siklus II.

Seperti yang diungkapkan oleh Jamalus (1988, 66) bahwa bermain musik dengan menggunakan alat-alat musik kelas, memberikan pengalaman yang dapat meningkatkan minat anakanak dalam belajar musik. Pada 236 umumnya anak-anak ingin memegang alat musik itu, dan ingin mencoba memainkannya. Oleh karena itu, anak menyukai bermain alat musik.

\section{KESIMPULAN}

Berdasarkan hasil penelitian dan pembahasan yang dilakukan, dapat disimpulkan bahwa Proses pembelajaran melalui bermain alat musik dol meliputi tahap pembukaan atau awal, tahap inti dan tahap akhir atau penutup.

Bermain alat musik dol dilakukan dengan memainkan alat musik perkusi (alat musik irama) yang memberikan pengalaman musik bagi anak guna menunjang aktivitas dari aspek-aspek kemampuan musikal yang berkaitan dengan unsur irama, seperti meniru irama, merespon irama dan membedakan irama.

Bermain alat musik dol dapat meningkatkan kemampuan musikal yang menfokuskan pada unsur penanaman rasa irama anak kelompok B PAUD Al-Khair Bengkulu.

\section{DAFTAR PUSTAKA}


Campbell, Patricia Shehan \& Kassner, Carol Scott. Music in Chilhood USA: Schirmer, 2006.

Faßhauer1, Caroline. Dkk. Musical ability is associated with enhanced auditory and visual cognitive processing. Jurnal Ebsco New york: Biomad Central, 2015.

Goode, B., Caroon. Optimizing Your Child's Talent. Jakarta: Kelompok Gramedia, 2005.

Gordon, Claire \& Cooper, Lynn Huggins. Meningkatkan 9 Kecerdasan Anak. Jakarta: Kelompok Gramedia, 2013.

Greenberg, Marvin. Your children Need Music. Englewood Cliffs: Prentice Hall, 1979.

Jamalis. Pengajaran Musik Melalui Pengalaman Musik. Jakarta: P2LPTK, 1988.

Mudjilah, Hanna Sri. Pengembangan Tes Kemampuan Musikal Anak. Jogjakarta: UNY, 2011.

Pica, Rae. Experiences in Movement \& Music. Australia: Wadsworth Cenagange Learning. 2013.

Rasyid, Fathur. Cerdaskan Anakmu dengan Musik. Jogjakarta: Diva Press, 2010.

Sumaryanto, Totok. Kemampuan Musikal (Musical Ability) dan Pengaruhnya Terhadap Prestasi Belajar Musik. Surabaya: Unnes, 2011. 